\title{
LINGUISTICS
}

\section{GENERAL AND SPECIFIC CULTURE LEARNING IN EFL TEXTBOOKS AIMED AT ADULT LEARNERS IN SPAIN}

\author{
ANTONIO R. RAIGÓN RodRÍGUEZ* AND ÁNGELA Ma LARREA ESPINAR
}

\author{
Universidad de Córdoba
}

\begin{abstract}
Since language teaching in modern-day society is closely linked to cultural instruction, this study employs the model of a cultural learning analysis based on the earlier work of Paige and Lee. Using this model, the authors analysed the cultural content of six B1 and B2-level textbooks for teaching English to adults in Spain, and carried out a comparative study of the results, contrasting the two levels. Findings show that the subjective aspects of culture receive less coverage in textbooks, despite being fundamental to an understanding of the values of a society. Regarding the comparison between B1 and B2 levels, the data indicate that the number of big "C" Culture occurrences is similar for both levels, although there are differences in other cultural aspects. So, for example, culture in general is dealt with more at the B1 level, whereas small "c" culture is dealt with more at the B2 level.
\end{abstract}

Keywords: Culture learning, textbook, EFL, big "C" Culture, small "c" culture

\section{Introduction}

Cultural knowledge has always been an integral part of language learning (Howatt \& Widdowson 2004). However, the development of behaviours, skills, and abilities did not gain the importance they deserve until the twenty-first century. Globalization and technology have made intercultural encounters more frequent than ever, which has led to a new focus on language teaching. The goal of communicative competence of the 1980s has largely been replaced by the goal of

Corresponding author: Antonio R. Raigón Rodríguez (antonio.raigon@uco.es). Universidad de Córdoba. Facultad de Filosofía y Letras. Plaza del Cardenal Salazar 3. 14003, Córdoba, Spain. 
intercultural communicative competence; thus the aim of language teaching is to enable students to negotiate cultural meanings and communicate effectively when it comes to interacting with speakers from other cultures. In Europe, the teaching of English as a foreign language is organised in accordance with the guidelines set out in the Common European Framework of Reference (CEFR). Despite the fact that the Framework recognises and endorses the acquisition of a cultural component, it does not establish specific descriptors for how this is to be achieved. Therefore, the first stage of the present study consists of designing a cultural learning model based on previous research by Paige, Jorstad, Paulson, Klein \& Colby (1999) and Lee (2009). Once created, this model is used to analyse the cultural content of six English language textbooks for B1 and B2-level adults. The authors' intention is to identify examples of cultural content and determine which type of cultural teaching is being carried out. The ultimate aim is to establish whether the cultural learning taking place is appropriate and conducive to the development of intercultural communicative competence, as set out in the CEFR.

2. The intercultural focus in language teaching

Ever since the emergence of the Sapir-Whorf hypothesis (Whorf 1956), countless studies have highlighted the interrelationship between culture and language, (Kramsch 1998; Brown 2000; Mitchell \& Myles 2004; Liddicoat, Papademetre, Scarino \& Kohler 2003).

The conviction that language and culture are two inseparable sides of the same coin has a direct bearing on language teaching: "Language and culture are not separate, but are acquired together, with each providing support for the development of the other" (Mitchell \& Myles 2004: 235). Despite this interrelationship, cultural teaching was a neglected component of language teaching in the $20^{\text {th }}$ century until the advent of the communicative approach in the $1980 \mathrm{~s}$, which renewed and reinforced the link between language and culture.

Resting on pragmatic and socio-linguistic foundations, the communicative teaching of language focuses on the use of language in a social context in a way that is culturally appropriate and competent. The incorporation of the cultural component into language teaching thus reflects a shift in emphasis that gives primacy to the communicative over the linguistic component.

Byram notes the link between language and culture when he states that "when learners learn about language, they learn about culture and as they learn to use a new language they learn to communicate with other individuals from a new culture" (1989: 22).

The cultural diversity implicit in globalisation, however, means that communicative competence proves insufficient for our desire to interact with people with different origins (Lárzen-Östermark 2009). As Sercu (2005) rightly points 
out, all communication in a foreign language is, by definition, intercultural. Full comprehension requires more than the mere transmission and reception of linguistic signs, because perceived reality arrives filtered, as we have seen, by our cultural values and beliefs.

So intercultural communicative competence (ICC) is the ability "to ensure a shared understanding by people of different social identities, and [the] ability to interact with people as complex human beings with multiple identities and their own individuality" (Byram, Gribkova \& Starkey 2002: 10).

Byram (1997) identifies the basic components of ICC: attitudes (for example, curiosity, openness, readiness to suspend one's own beliefs, etc.), knowledge (about social groups and their products), skills of interpreting (a document or event from another culture) and relating (it to one's own), skills of discovery and interaction (under the pressure of real life interaction), critical cultural awareness/political education (evaluate critically practices and products in one's own and other cultures).

Intercultural competence, therefore, "involves looking at culture as not just knowledge, but also a set of skills, behaviours, and attitudes that help a person succeed in a cross-cultural environment" (Watson, Siska \& Wolfel 2013: 64). In this sense, the ability to decentralise and a positive attitude are the pillars that sustain intercultural communication.

The new intercultural speakers, therefore, are those who feel comfortable among people who have cultural baggage different to their own, who are capable of accepting the difference and do not feel threatened by it. Moreover, they are able to objectify their own beliefs, to negotiate, to make themselves understood and to make the effort to understand others.

In this sense, it proves more appropriate and practical to foster students' cultural knowledge by having recourse to various cultures and developing intercultural competence: "Learners should begin by realising and understanding their own culture, respecting others' cultures and being culturally sensitive" (Lai 2014: 6).

\section{The cultural component in textbooks}

Although they have their detractors, textbooks continue to form the backbone of language teaching in the classroom (Sercu 2000).

In the case of teaching English as a foreign language, various studies have looked at the cultural component in textbooks. Numerous authors in Spain have addressed the subject of the cultural dimension in textbooks and other materials for learning foreign languages, among them Puig (1996), Areizaga (2002), and Paricio (2005). Outside Spain the subject has attracted wider attention: Kramsch (1988), Risager (1991), Sercu (2000), Lee (2009), Zarei \& Khalessi (2011), Weninger \& Kiss (2013), McConachy \& Hata (2013). 
In terms of the way culture is treated in textbooks, one of the main problems to have been identified is that cultural teaching is limited to the objective transmission of information (Kramsch 1993). Cerezal (1999) argues that cultural teaching in many textbooks is oriented towards the acquisition of linguistic competence, to the detriment of pragmatic and sociocultural competences. This leads to a fragmented and stereotyped view of the foreign culture. Moreover, this type of cultural teaching is based on the erroneous equation of cultural teaching to the teaching of the L2 culture, associated with a particular group of people (Risager 1998).

Students therefore not only need to come to terms with the culture or cultures of the target language, but also relate to the world that surrounds them, a global world: "the culture related to English refers to not only the target culture(s) of the language but also the broader inclusion of the world as a complete entity" (Cheng 2012: 165). Tomlinson points out an additional problem for editorial teams: "in attempting to cater for all students at a particular age and level, global coursebooks often end up not meeting the needs and wants of any" (2012: 158).

In this sense, the status of English as a language of intercultural communication (World English) entails that Spanish students will have to communicate with people from other cultures and need to be sensitive to the fact that "people from different cultures tend to use English differently" (Lee 2012: 193). As Shin, Eslami \& Chen state, "[i]n terms of cultural content, mass-produced textbooks presenting a single target culture no longer meet the needs of students learning an international language" (2011: 266).

In the case of English as a foreign language, curricular planning in Europe follows the CEFR guidelines for languages. Drawing on Byram's intercultural communication theory, the framework has as its fundamental aim the production of intercultural speakers who are able to "see how different cultures relate to each other in terms of similarities and differences and to look at themselves from an 'external' perspective when interacting with representatives of other cultures" (Larzén-Östermark 2008: 528). The design of textbook content for teaching English as a foreign language should therefore reflect this aim.

Although the cultural component is a recurring theme in the CEFR, it is specifically dealt with in chapter 5 . Here, there are abundant references to cultural acquisition in the competences of the user or student, in particular in section 5.1, "General Competences", and section 5.2, "Communicative language competences".

Among the general competences is declarative knowledge (savoir), skills and know-how (savoir faire), existential competence (savoir-être) and the ability to learn (savoir-apprendre). Knowledge (savoir) is in turn made up of sociocultural knowledge and intercultural awareness, while savoir faire encompasses intercultural skills and know-how. 
With regard to the communicative competences, apart from linguistic and pragmatic competences, mention is made of sociolinguistic competence, which refers to the sociocultural conditions: "Sociolinguistic competence is concerned with the knowledge and skills required to deal with the social dimension of language use" (CEFR 2001: 118).

These competences are to be acquired in a step-by-step manner in accordance with the user's or student's level. Thus the CEFR provides graduated descriptors for distinct aspects of the communicative competences (linguistic, pragmatic, and sociolinguistic), although it does not offer descriptors for the general competences, which include the cultural dimension: "Its definition of intercultural competence is, however, limited to the linguistic treatment of sayings, expressions, different registers and social varieties of language" (Göbel \& Helmke 2010: 1571).

Having designed a model of cultural learning based on the earlier models of Paige et al. (1999) and Lee (2009) and carried out an analysis of the cultural content of six textbooks for teaching English at the B1 and B2 levels, the present study set out to compare the two levels of textbooks. The aim of this paper, therefore, is to highlight incidences of cultural learning in the design of the selected textbooks and identify which type of cultural manifestation predominates. The ultimate aim is to determine whether the cultural learning that is taking place is appropriate to developing each and every one of the competences that lead to an integrated learning of language and cultures, i.e., the intercultural communicative competence as set out in the CEFR for both levels.

\section{Model of cultural learning}

Paige et al. (1999) put forward a conceptual model of cultural learning, building on the earlier contributions of Byram (1997) and Kramsch (1993), with the aim of integrating the teaching/learning of language and culture. They define cultural learning as:

\footnotetext{
“(...) the process of acquiring the culture-specific and culture-general knowledge, skills, and attitudes required for effective communication and interaction with individuals from other cultures. It is a dynamic, developmental, and on-going process which engages the learner cognitively, behaviourally, and affectively" (1999: 50)
}

The definition of cultural learning proposed by this group of authors is highly relevant to current cultural teaching. First, it highlights the fact that, for learning to be complete, students need to acquire aspects of culture in both the general and specific sense. Secondly, it alludes to a dynamic, evolving, process in which the two cultural aspects are rendered effective from a cognitive, behavioural and affective perspective. In other words, "the culture learning/teaching 
goals and outcomes claimed by Paige and his associates are both culture-general and culture-specific knowledge, behaviour and attitudes" (Lee 2009: 78).

Table 1: Conceptual model for culture learning (Paige et al. 1999: 54)

\begin{tabular}{lll}
\hline Knowledge & \multicolumn{1}{c}{ Culture-general } & \multicolumn{1}{c}{ Culture specific } \\
& Intercultural phenomena: & Little 'c' target culture \\
& Cultural adjustment stages & knowledge \\
& Culture shock & Big 'C' target culture \\
& Intercultural development & knowledge \\
& Culture learning & Pragmatics \\
& Cultural identity & Sociolinguistic competence \\
& Cultural marginality & \\
\hline Behaviour & Intercultural skills: & Target culture skills: \\
& Culture learning strategies & Little 'c' culture - appropri- \\
& Coping and stress management & ate everyday behaviour \\
& strategies & Big 'C' Culture -appropriate \\
& Intercultural communicative & contextual behaviour \\
& competence & \\
Intercultural perspective-taking & \\
skills & Cultural adaptability & \\
& Transcultural competence & \\
\hline Attitudes & $\begin{array}{l}\text { Positive attitude toward different } \\
\text { cultures }\end{array}$ & Positive attitude toward \\
& Positive attitude toward culture & Positive attitude toward \\
& learning & target culture persons \\
& Ethnorelative attitude regarding & \\
cultural differences & \\
\hline
\end{tabular}

In the case of culture in general, learning is focussed on the acquisition of knowledge, skills and attitudes of a more general character that are transferable to other cultures (Paige et al. 1999). Ware \& Kramsch (2005) support the idea put forward by Paige et al. that this knowledge is essential for the learning of languages.

Culture-specific learning involves acquiring knowledge, behaviours and attitudes related to a particular cultural group or community. Having said this, Paige et al. (1999) explicitly state that specific culture refers both to big "C" Culture and small "c" culture. Big"C $\mathrm{C}$ " Culture encompasses easily-observable events and statistics related to art, history, education, festivals, customs, etc. Examples of small "c" culture, on the other hand, include sociocultural values, norms, beliefs, assumptions, etc., which are less visible. 
Lee (2009) used the model developed by Paige et al. (1999) with a classification by themes, which makes it more objectifiable and applicable to the model of an analysis of curricular material. He also classified the occurrences by formal presentation type - dialogue, image or activity - depending upon how the cultural aspect was presented in the book.

As far as the learning of culture in general is concerned, Lee suggested 16 themes. So for the acquisition of knowledge, he added three themes to the earlier model (The self as a cultural being, Impact of culture on human communities and Culture stress); in the behaviour section he eliminated Transcultural competence and changed Coping and stress management strategies to Strategies dealing with intercultural stress; finally, in the attitude section he eliminated the Positive attitude toward different cultures.

With regard to the learning of specific culture, to acquire aspects of big " $\mathrm{C}$ " Culture, Lee (2009) used 22 categories, following Paige et al. (1999) and Hinkel (2001). For learning aspects of small "c" culture, however, he sketched out 26 areas based on intercultural, ethnographic, sociological, and sociolinguistic perspectives.

Although it constitutes a good starting point, Lee's (2009) model struck the present authors as being too detailed to be practical when it came to analysing the materials. They therefore designed their own model of cultural learning for the present study, adapting earlier models.

Thus, for general cultural acquisition ten categories were proposed, while for specific culture 14 categories were proposed in the learning of big " $\mathrm{C}$ " Culture and 16 categories in small "c" culture, considerably reducing Lee's list of categories. The authors have thus combined certain categories that may be considered as falling within the same spectrum (for example Cultural adjustment and Culture shock in culture in general, and Infrastructure/metropolitan and Traffic/transportation in big " $\mathrm{C}$ " Culture), and eliminated others that proved to be redundant or difficult to identify in a textbook due to being excessively specific (High involvement and Experimental in small "c" culture, to give but two examples). The authors believe that these changes help to provide a more functional model without jeopardising effectiveness or rigour, given that the categories included are representative, and encompass the acquisition of the knowledge, skills and attitudes needed to communicate and interact in an effective way with individuals of other cultures. 
5. Materials and method for the study

The authors decided to focus on books for teaching English as a foreign language to adults because of their university experience. First, three publishers with a good reputation in the field of English teaching for adults in Spain were chosen, each with a significant share of the Spanish market: Oxford University Press (OUP), Macmillan Publishers (MP), and Cambridge University Press (CUP). These publishers have many years of experience in the sector and they have large teams of professionals working on the creation and development of their books. Secondly, within the range of resources that they offer, the current authors chose up-to-date English courses adapted to the specifications of the CEFR. Finally, since each course has textbooks corresponding to the different CEFR levels, the authors restricted the study to B1 (Intermediate) and B2 (Upper Intermediate) textbooks:

i. OUP: English file intermediate (2013) and New English file upperintermediate $(2008)^{1}$; henceforth $\mathrm{EF}$.

ii. CUP: English unlimited intermediate (2011) and English unlimited upper intermediate (2011); EU.

iii. MP: Straightforward intermediate (2012) and Straightforward upper intermediate (2012); henceforth SF.

The choice of these two levels was determined by the fact that level B1 is the threshold for a traveller visiting a foreign country (known as the "threshold" level) and the level required of university students in order to graduate, while B2 is the advanced or "vantage" level, which university students need in order to have access to the most common foreign-study grants (Erasmus + , for example). According to the CEFR, B1 users should be able to interact and make themselves understood in a variety of situations, and tackle day-to-day problems in a flexible way.

B2 represents a higher level. Students acquire a new perspective and are able to view their surroundings in a new way. Thus, for example, they develop the ability to state an opposing view.

The sociolinguistic adaptation set out in the document makes it clear that cultural learning is an essential aspect of developing the competences envisaged:

The editions chosen were the most recently published at the time of conducting the study. While the article was being written however, a new edition of the New English File for the B2 level was published. 
Table 2. Common European Framework of Reference for Languages (CEFR 2001: 24)

\begin{tabular}{c|l|l}
\hline \multirow{2}{*}{$\begin{array}{c}\text { Independent } \\
\text { user }\end{array}$} & $\begin{array}{l}\text { Can understand the main points of clear standard } \\
\text { input on familiar matters regularly encountered in } \\
\text { work, school, leisure, etc. Can deal with most situa- } \\
\text { tions likely to arise whilst travelling in an area where } \\
\text { the language is spoken. Can produce simple con- } \\
\text { nected text on topics which are familiar or of personal } \\
\text { interest. Can describe experiences and events, } \\
\text { dreams, hopes and ambitions and briefly give reasons } \\
\text { and explanations for opinions and plans. }\end{array}$ \\
\cline { 2 - 3 } & B2 & $\begin{array}{l}\text { Can understand the main ideas of complex text on } \\
\text { both concrete and abstract topics, including technical } \\
\text { discussions in his/her field of specialisation. Can } \\
\text { interact with a degree of fluency and spontaneity that } \\
\text { makes regular interaction with native speakers quite } \\
\text { possible without strain for either party. Can produce } \\
\text { clear, detailed text on a wide range of subjects and } \\
\text { explain a viewpoint on a topical issue giving the ad- } \\
\text { vantages and disadvantages of various options. }\end{array}$ \\
\hline
\end{tabular}

With regard to the method, the model of cultural learning employed in this study encompasses the acquisition of culture in general and specific culture (divided into big "C" and small "c" culture). Three tables were consequently drawn up, one for each aspect of cultural learning.

Thus, Table 3 shows the acquisition of culture in general, while Tables 4 and 5 focus on specific culture: Table 4 on big "C" Culture and Table 5 on small "c" culture.

The study uses a quantitative approach based on the observation of cultural occurrences. The authors of this study coded the data. The cultural occurrences were categorized and recorded as shown in the tables. When an activity was found to deal with more than one category, the same activity was recorded under the different categories.

Each table sets out the various categories proposed for learning this type of culture, the name of the textbook, its level and the frequency of cases found in the book.

For the purposes of analysing the cultural learning content, only the textbooks themselves were studied, ignoring any complementary course material such as CD-ROMs, workbooks, websites, online activities etc. The only exception to this was the English File Intermediate textbook, where a series of videos 
and songs were included because they are presented in the textbook as activities that should be undertaken in the classroom, something that did not apply in the other cases.

Table 3. Content analysis: Culture in general

\begin{tabular}{|c|c|c|c|c|c|c|c|}
\hline \multicolumn{2}{|c|}{ CULTURE IN GENERAL } & $E F$ & $E U$ & $S F$ & $E F$ & $E U$ & $S F$ \\
\hline \multirow{4}{*}{ 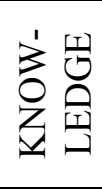 } & Cultural learning & 28 & 14 & 20 & 12 & 38 & 15 \\
\hline & Cultural adjustment stages (shock) & 2 & 3 & & 1 & 3 & \\
\hline & Intercultural development & 1 & 5 & & & 11 & 9 \\
\hline & Cultural identity & 8 & 19 & 14 & 6 & 15 & \\
\hline \multirow{4}{*}{ 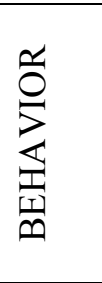 } & Culture learning strategies & 1 & 2 & & & 6 & \\
\hline & $\begin{array}{l}\text { Strategies dealing with intercultural } \\
\text { stress }\end{array}$ & & 1 & & & 2 & \\
\hline & $\begin{array}{l}\text { Intercultural communicative com- } \\
\text { petence }\end{array}$ & 1 & 2 & & & 8 & \\
\hline & Cultural adaptability & 1 & 3 & & & 3 & \\
\hline \multirow{2}{*}{ 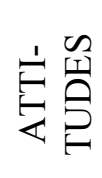 } & $\begin{array}{l}\text { Positive attitude toward cultural } \\
\text { learning }\end{array}$ & 17 & 13 & 1 & 2 & 9 & 2 \\
\hline & $\begin{array}{l}\text { Positive attitude toward cultural } \\
\text { differences }\end{array}$ & 2 & 8 & 1 & 1 & 7 & \\
\hline
\end{tabular}

B1. The B1 books include 167 examples of general cultural learning. The most commonly-addressed themes are Cultural learning and Cultural identity, both belonging to the knowledge dimension. The third most common theme is Positive attitude toward cultural learning, part of the attitudes group. It is clear, therefore, that themes related to knowledge predominate in all three textbooks (114 examples), while the attitudes and behaviour sections are less wellrepresented (42 and 11 examples, respectively). It is also worth pointing out that the Straightforward textbook does not contain a single case of content addressing behavioural issues.

The textbook that appears most comprehensive, given that it covers each of the themes included in learning culture in general, is $E U$, with 70 occurrences. It is followed by $E F$, with 61 occurrences and finally $S F$, with 36 .

B2. In the B2 textbooks, 140 occurrences of learning culture in general were found. The themes most frequently covered were Cultural learning (55 cases) followed by Cultural identity and Intercultural development (with 21 and 20 occurrences respectively). All three themes belong to the knowledge dimension. 
It is thus clear that knowledge themes predominate, while attitudes and behaviours receive less coverage ( 21 and 19 occurrences respectively). Just as with the B1 level, it is noteworthy that the $S F$ textbook has no behavioural content.

$E U$ emerged as the most complete textbook in addressing the learning of culture in general, given that it features a total of 92 occurrences (of the 140 in total) and addresses all the themes included in the table. $S F$ occupied second place with 26 occurrences, followed by $E F$, with 22 .

Table 4. Specific culture: Big "C" Culture

\begin{tabular}{lrrrrrr}
\hline BIG “C” CATEGORIES & $E F$ & $E U$ & $S F$ & $E F$ & $E U$ & $S F$ \\
& $B 1$ & $B 1$ & $B 1$ & $B 2$ & $B 2$ & $B 2$ \\
\hline Ethnic groups & 2 & 17 & 3 & 3 & 14 & 2 \\
Geography/history/politics/regional variations & 2 & 2 & 15 & 1 & 6 & 8 \\
Arts/crafts/monuments and historical sites & 3 & 3 & 8 & 2 & 10 & 4 \\
Literature, films, music, and mass media & 27 & 7 & 12 & 15 & 9 & 10 \\
Currency/shopping/market/industry/business & 2 & 1 & 4 & 2 & 11 & 4 \\
Urban & 7 & 2 & 7 & 7 & 5 & 3 \\
life/infrastructure/housing/transportation & & & & & & \\
Education & 4 & & 1 & & 7 & \\
Dress-style & 2 & & & 2 & 2 & 2 \\
Food & 1 & 1 & 3 & & 4 & \\
Festivals/celebrations/holidays/ceremonies & & & 1 & 1 & 7 & 1 \\
Social customs & 8 & 15 & 10 & 8 & 13 & 6 \\
Leisure/sports & 1 & 2 & 3 & & 2 & 6 \\
Family & 1 & 7 & 1 & & 3 & 1 \\
Non-verbal com. (personal space, oculesics, & & & & & & \\
haptics...) & & 3 & & 1 & 4 & 1 \\
\hline
\end{tabular}

B1. With regard to the learning of big "C" Culture, within the field of specific culture, analysis of the three B1 textbooks revealed 188 occurrences. The three most frequent themes were Literature, films, music, and mass media (46 occurrences), Social customs (33), and Ethnic groups (22). The least frequent were Festivals/celebrations/holidays/ceremonies" and Dress-style (with one and two occurrences, respectively).

The textbook that features the most content for learning big " $C$ " Culture is $S F$ with 68 occurrences. It is followed by $E F$ and $E U$, both with the same number of cases $(60)$. 
B2. Analysis of the B2 textbooks for the learning of big "C" Culture reveals 191 examples. The most frequently recurring themes were Literature, films, music, and mass media" (34 occurrences), Social customs (27), and Ethnic groups (19). The least frequent were Food and Family (both with four cases).

Consequently, the textbook that most addresses the learning of big " $\mathrm{C}$ " $\mathrm{Cul}-$ ture is $E U$, with 98 occurrences. $S F$ comes second with 48 and finally $E F$, with 45 occurrences.

Table 5. Specific culture: Small "c" culture

\begin{tabular}{lrrrrrr}
\hline SMALL "c" CATEGORIES & $E F$ & $E U$ & $S F$ & $E F$ & $E U$ & $S F$ \\
& $B 1$ & $B 1$ & $B 1$ & $B 2$ & $B 2$ & $B 2$ \\
\hline Individualism/collectivism & & 3 & 1 & 1 & 4 & 1 \\
Equality & 1 & 1 & 1 & & 6 & 2 \\
Fairness & 1 & & & 3 & 6 & 3 \\
Competition & 1 & 1 & & & 3 & 1 \\
Materialism & & & 1 & 2 & 2 & 2 \\
$\quad$ Confrontation & 4 & 5 & & & 5 & 1 \\
Novelty oriented (newer is better) & & & & & 2 & \\
Self-improvement & 2 & 4 & & 1 & 3 & 2 \\
Nurture (up-bringing, education) & 1 & & & 1 & & 1 \\
Time & 3 & & 1 & & 8 & 1 \\
Level of formality & 3 & 5 & & & 8 & \\
Com. styles: direct vs. indirect & & 3 & 1 & 3 & 5 & \\
Rules-regulation oriented & & 3 & & & & 2 \\
Male-oriented & & 2 & & & 3 & 2 \\
Result-oriented & & 3 & & & 2 & \\
Importance of hard work & & & & &
\end{tabular}

B1. Analysis of the learning of small "c" culture in the B1 textbooks shows 53 occurrences. The themes most commonly dealt with were Confrontation and Communication styles: direct vs. indirect (with nine and eight cases respectively). One theme was not covered in any of the textbooks: Novelty oriented, while there were three themes that were only covered once: Fairness, Materialism, and Time.

The textbook containing the greatest number of examples and themes (11 out of 16) for the learning of small "c" culture was $E U$, with 32 occurrences, accounting for more than half of the total figure of 53. $E F$ occupies second place, with 16 occurrences, while last place is taken by $S F$, with only 5 . 
B2. Analysis of the B2 textbooks in terms of learning small "c" culture reveals 96 cultural occurrences in total. The themes that occur most frequently are Fairness (12 cases) and Nurture (11). The least-frequently covered theme is Time, with only one example. It is worth mentioning that examples of all 16 themes included under the heading small "c" culture were found.

The data reveal that the textbook containing the greatest number of occurrences (66 out of the 96 in total) and the greatest number of themes (14 out of a possible 16) for learning small "c" culture was $E U$. $S F$ occupied second place, with 18 examples and $E F$ was in last place, with 12.

6. Comparison of the levels and analysis of the results

The next step was to carry out an analysis of the cultural occurrences in B1level textbooks compared to those at the B2 level.

\subsection{Culture in general}

A comparison of the two levels of the books chosen showed that culture in general is addressed more in B1-level books than their B2 counterparts.

The most frequently occurring themes were Cultural learning and Cultural identity for both levels; although at B2 level the second theme is followed very closely by Intercultural development. The knowledge dimension plays a predominant role in both levels. In both cases it is followed by attitudinal content and, in last place, behavioural content (which, in the case of $S F$, is not addressed at either of the two levels).

Comparing the levels by series and publisher, it becomes evident that the number of occurrences of culture in general in $E F$ is much higher at B1 level than at B2 level. This may be due to the fact that $E F$ is the only one of the three titles chosen for the study with different publication dates. The intermediate book dates from 2013, while the upper intermediate book dates from 2008. This leads the authors to conclude that the new edition incorporates more content featuring culture in general.

In the case of $E U$, the B1 level shows fewer occurrences than B2. With $S F$ the opposite is the case, with a greater number of occurrences at the lower level (B1).

Table 6. Occurrences of culture in general in the textbooks

\begin{tabular}{lrr}
\hline & B1 & B2 \\
\hline EF & 61 & 22 \\
EU & 70 & 92 \\
SF & 36 & 26 \\
\hline Total & 167 & 140 \\
\hline
\end{tabular}


As far as the most frequently recurring themes are concerned, there is hardly any difference when comparing textbooks issued by the same publisher, which keep the same themes for both $\mathrm{B} 1$ and $\mathrm{B} 2$, except in the case of $E F$.

\subsection{Specific culture: big "C" Culture}

A comparative study of the two levels suggest that there is no substantial difference between B1 and B2 in terms of incorporating content that addresses big "C" Culture.

The most frequently recurring themes are also the same for both levels: Literature, films, music, and mass media, Social customs, and Ethnic groups. There is, however, a difference in the least-covered themes: the least common at the B1 level were Festivals/celebrations/holidays/ceremonies and Dress-style, while at the B2 level they were Food and Family.

Comparing the levels by series and publisher, $E U$, as mentioned previously, is the textbook that contains the highest number of examples of big " $\mathrm{C}$ " Culture at the B2 level (98 as opposed to 60 cases at B1); this is precisely the opposite of what occurs with the other two books, which contain fewer occurrences of big "C" Culture at the B2 level:

Table 7. Occurrences of Big "C" Culture in the textbooks studied

\begin{tabular}{lrr}
\hline & B1 & B2 \\
\hline EF & 60 & 45 \\
EU & 60 & 98 \\
SF & 68 & 48 \\
\hline Total & 188 & 191 \\
\hline
\end{tabular}

In terms of the most frequent themes at $\mathrm{B} 1$ and $\mathrm{B} 2$, in $E F$ there is no difference in the most frequently covered theme, which is the same at both levels: Literature, films, music, and mass media. Nor was there any difference in the most frequent theme addressed in the CUP publication, EU, with Ethnic groups recurring most often at both levels. Finally, there were differences in $S F$ in the most frequent themes when comparing the two levels. Geography/history/politics/regional variations was the most frequent theme at the B1 level whereas at the B2 level it was Literature, films, music, and mass media.

\subsection{Specific culture: small "c" culture}

A comparison of the two levels shows that there is a substantial difference between B1 and B2 in terms of including content for learning small "c" culture. 
This type of learning is tackled more at the B2 than the B1 level, as the number of occurrences identified in the books demonstrates. As far as the mostfrequently recurring themes are concerned, there are differences between the levels. At the B1 level the most frequently recurring themes were Confrontation and Communication styles: direct vs. indirect, while at the B2 level they were Fairness and Nurture. At the B1 level there is a theme that was not covered at all, Novelty oriented, whereas all the themes are covered at the B2 level, with the least frequent being Time, with one occurrence.

The comparative data for books in the same series and publisher indicate that the $E F$ series has a higher number of occurrences at the $\mathrm{B} 1$ level related to small "c" culture, precisely the opposite of what occurs with the other two series, which have more small "c" culture content at B2. This may be due to the fact that, as noted earlier, the $\mathrm{B} 2$ publication is older than its B1 counterpart.

Table 8. Occurrences of small "c" culture in the textbooks studied

\begin{tabular}{lrr}
\hline & B1 & B2 \\
\hline EF & 16 & 12 \\
EU & 32 & 66 \\
SF & 5 & 18 \\
\hline Total & 53 & 96 \\
\hline
\end{tabular}

With regard to the most-frequently recurring themes in books of the same series, the most common themes in $E F$ are different for the two levels. The most recurring theme at $\mathrm{B} 1$ the level is Confrontation, whereas at the B2 level there were two frequent themes, Fairness and Rules-regulation oriented.

Turning next to the $E U$ series, one theme that stands out at both the $\mathrm{B} 1$ and B2 levels is Communication styles: direct vs. indirect. This is the most frequent theme at B1 together with Confrontation, and the second most-frequent theme at B2, the first being Nurture.

The $S F$ series does not feature any recurring themes at the B1 level, although there is one at the B2 level, namely Fairness. What stands out with the less frequently recurring themes is the fact that 11 themes are not covered at all at the B1 level. This number falls at the B2 level, with only five themes absent.

\section{Discussion of the results}

This comparative analysis of the cultural occurrences classified by level together with the cultural aspect treated also provides the following results: 
a) In general, the cultural aspect most covered by the textbooks is big "C" $\mathrm{Cul}$ ture, as is indicated by the total number of occurrences. Culture in general occupies second place while coverage of small "c" culture comes last:

Table 9. Total number of cultural occurrences classified by level and cultural aspect

\begin{tabular}{lrr}
\hline & B1 & B2 \\
\hline Culture in general & 167 & 140 \\
Big "C" Culture & 188 & 191 \\
Small "c" culture & 53 & 96 \\
\hline
\end{tabular}

b) Comparing the treatment of cultural aspects at the two levels, it is evident that there is no substantial difference between B1 and B2 in the frequency of big " $\mathrm{C}$ " Culture. This suggests that this aspect is covered more or less equally at both levels. There are differences, however, in the way the other cultural aspects are treated. The data indicate that at the B1 level more aspects of general culture are included whereas at the B2 level more aspects of small "c" culture are present.

A cultural analysis of the six books indicates that the most complete title in terms of cultural acquisition, measured both by the themes covered and by the number of cultural occurrences, is English Unlimited, and this applies both to the B1 and the B2 level publications. Thus, both textbooks include a specific section devoted to cultural aspects (Across Cultures) every two units. The activities presented in this section promote meaningful cultural learning. As an example, on page 13 of the B1 level textbook, students are engaged in a speaking activity where they need to talk about their intercultural experiences abroad and are specifically asked about the cultural differences encountered. Then, they listen to Federico, an Argentinean working in Egypt, who talks about the differences between both cultures, and reflects about cultural clashes and his personal development in adjusting to the new culture. Likewise, the B2 level textbook uses the same Across Cultures pattern. An example can be found on pages 64 and 65, which deals with critical incidents and intercultural misunderstandings. This type of activity provides students with an opportunity to become culturally aware and so they can work on their cultural skills and attitudes rather than just concentrating on factual knowledge.

However, the B1 level book would benefit from an increase in the number of occurrences and themes related to big "C" Culture, given that Straightforward Intermediate is slightly superior in this respect.

On the contrary, an anecdotic treatment of cultural learning can be found in the $S F$ series. On $S F$ B1, the Did you know? Section (page 41) presents a short 
reading about superstitions in the UK. The follow-up activity asks students "which birds or animals in your country are considered to be lucky or unlucky?" and "what other superstitions are common?" This is nothing more than a superficial view of culture. Another example to illustrate this can be found on $S F$ B2 (unit 11B, South is up). This unit shows a picture of the world map "upsidedown". Instead of using this to discuss deeper issues of culture in general such as ethnocentrism (e.g. the place of Europe and the rest of the world in western maps), the speaking activities ask students to discuss what maps they have at home and how often they use them.

Somewhere in between $E U$ and $S F$ lies $E F$ in the treatment of culture. For example, unit 1A of $E F$ B1 (page 6) introduces an activity where students have to listen out for the main differences between British and Spanish customers in restaurants. The follow-up discussion poses the question whether people from the student's own country would normally tell the waiter/chef what they really think about the food. This type of question goes beyond the anecdotic but it is still short from developing positive attitudes toward other cultures.

Following our study, we have identified some weaknesses that textbook editors should address in order to improve cultural learning:

1) Many discussion questions are so superficial (from a cultural standpoint) that they do not engage students in cultural self-awareness or introduce diverse cultural realities. Most of the follow-up questions presented in the analyzed textbooks have great potential for cultural learning that is not usually fully exploited.

2) In relation to the learning of culture in general, many activities deal with cultural differences but are short from helping students develop positive attitudes toward other cultures. This is key to achieving intercultural development and understanding.

\section{Conclusions}

The competence-based model established by the CEFR rests upon Byram's (1997) theory of intercultural communication. The cultural component is thus included as a central element in the acquisition of a foreign language. Cultural learning/teaching is difficult to measure and plan for, which is why the CEFR does not give specific descriptors for the general competences, among them being the cultural dimension.

The first aim of the present study was thus to design a cultural analysis model based on the earlier models of Paige et al. (1999) and Lee (2009). Next, three well-known and prestigious publishers were chosen and for each publisher 
the most up-to-date and functional textbook series for teaching English as a foreign language to adults were identified. For each series, the B1 (Intermediate) and B2 (Upper Intermediate) level books were singled out and each book was analysed in accordance with the cultural learning model adopted.

The results proved extremely interesting, in that they revealed which aspect of culture receives most coverage and whether there is any difference depending on the level. Lee's (2009) research into this question indicates that aspects related to big "C" Culture predominate, i.e. the objective and visible elements of culture, to the detriment of culture in general and small "c" culture. The present study confirmed earlier findings in that big " $\mathrm{C}$ " Culture accounted for the greatest number of general occurrences. The data from the analysis also showed that the second most frequently treated aspects were those relating to culture in general, while the least covered were those relating to small "c" culture. Varón (2009) has already noted this phenomenon, pointing out that the treatment of invisible culture in textbooks is limited in most cases to anecdotal and peripheral information.

With regard to the results of the comparative study of the levels, it is evident that there is scarcely any difference between the two levels in the number of occurrences of big "C" Culture. There are, however, significant differences in the data with respect to culture in general and small "c" culture. The analysis shows that culture in general is addressed more at the B1 than the B2 level, whereas the opposite is the case with small "c" culture, where there is a greater frequency of occurrences at the B2 level. Perhaps this is due to the fact that, because the B2 level is a higher level, it is easier for the learning material to incorporate subjective aspects, which require a greater degree of conceptualization. It would be interesting to pursue this line of enquiry and include lower level (A2) and higher level (C1) textbooks in the study to see whether this tendency is confirmed.

In any event, the present study shows that the invisible aspects of culture are the most neglected, despite the fact that they are essential for understanding a society's ways of thinking and values, providing insights that cannot be acquired if one is restricted to teaching big "C" Culture.

The ultimate aim of this paper was to determine whether the way culture is treated in textbooks enables a form of cultural learning that allows intercultural communicative competence at the B1 and B2 levels to develop. It seems to the authors that, although the treatment that culture receives in textbooks has changed for the better, including aspects of culture in general and small "c" culture, much remains to be done in the development of interculturally competent speakers, i.e. people who are able to detect the similarities and differences between distinct cultures and see themselves from an external perspective, a vantage point from which they can interact with people of other cultures. 


\section{REFERENCES}

\section{PRIMARY SOURCES}

Kerr, Philip \& Ceri Jones. 2012. Straightforward intermediate. Oxford: Macmillan Publishers.

Kerr, Philip \& Ceri Jones. 2012. Straightforward upper intermediate. Oxford: Macmillan Publishers.

Latham-Koenig, Christina \& Clive Oxenden. 2013. English file intermediate. Oxford: Oxford University Press.

Oxenden, Clive \& Christian Latham-Koenig. 2008. New English file upper-intermediate. Oxford: Oxford University Press.

Rea, David \& Theresa Clementson. 2011. English unlimited intermediate. Cambridge: Cambridge University Press.

Tilbury, Alex \& Leslie A. Hendra. 2011. English unlimited upper intermediate. Cambridge: Cambridge University Press.

\section{SECONDARY SOURCES}

Areizaga, Elisabet. 2002. El componente cultural en la enseñanza de lenguas: Elementos para el análisis y la evaluación del material didáctico. Cultura y Educación 14 (2). 161-175. doi: $10.1174 / 113564002760041550$

Brown, H. Douglas. 2000. Principles of language learning and teaching (4th edn.). New York, NY: Longman.

Byram, Michael. 1989. Cultural studies in foreign language education (Multilingual Matters 46). Clevedon: Multilingual Matters.

Byram, Michael. 1997. Teaching and assessing intercultural communicative competence (Multilingual Matters). Clevedon: Multilingual Matters.

Byram, Michael, Bella Gribkova \& Hugh Starkey. 2002. Developing the intercultural dimension in language teaching: A practical introduction for teachers. Strasbourg: Council of Europe.

CEFR = Council of Europe. 2001. Common European framework of reference for languages: Learning, teaching, assessment. Cambridge: Cambridge University Press.

Cerezal, Fernando. 1999. La transmisión de valores genéricos discriminatorios en libros de texto de inglés (Instrumentos didácticos 11). Alcalá de Henares: Servicio de Publicaciones, Universidad de Alcalá.

Cheng, Ching-Mei. 2012. The influence of college EFL teachers' understandings of intercultural competence on their self-reported pedagogical practices in Taiwan. English Teaching: Practice and Critique 11 (1). 164-182.

Göbel, Kerstin \& Andreas Helmke. 2010. Intercultural learning in English as foreign language instruction: The importance of teachers' intercultural experience and the usefulness of precise instructional directives. Teaching and Teacher Education 26(8). 1571-1582. doi:10.1016/j.tate.2010.05.008

Hinkel, Eli. 2001. Building awareness and practical skills to facilitate cross-cultural communication. In Marianne Celce-Murcia (ed.), Teaching English as a second or foreign language (3rd edn.), 443-458. Boston, MA: Heinle \& Heinle. 
Howatt, Anthony P. R. \& Henry G. Widdowson. 2004. A history of English language teaching (2nd edn.). Oxford: Oxford University Press.

Kramsch, Claire. 1988. The cultural discourse of foreign language textbooks. In Alan J. Singerman (ed.), Toward a new integration of language and culture, 63-88. Middlebury, VT: Northeast Conference on the Teaching of Foreign Languages.

Kramsch, Claire. 1993. Context and culture in language teaching (Oxford Applied Linguistics). Oxford: Oxford University Press.

Kramsch, Claire. 1998. Language and culture (Oxford Introductions to Language Study). Oxford: Oxford University Press.

Lai, Hsuan-Yau Tony. 2014. Learning English as an international language: EFL learners' perceptions of cultural knowledge acquisition in the English classroom. Asian Social Science 10(1). 1-11. doi: 10.5539/ass.v10n1p1

Lárzen-Östermark, Eva. 2008. The intercultural dimension in EFL-teaching: A study of conceptions among Finland-Swedish comprehensive school teachers. Scandinavian Journal of Educational Research 52(5). 527-547. doi: 10.1080/00313830802346405

Lárzen-Östermark, Eva. 2009. Language teacher education in Finland and the cultural dimension of foreign language teaching - a student teacher perspective. European Journal of Teacher Education 32(4). 401-421. doi: 10.1080/02619760903012688

Lee, Kang-Young. 2009. Treating culture: What 11 high school EFL conversation textbooks in South Korea do. English Teaching: Practice and Critique 8(1). 76-96.

Lee, Kang-Young. 2012. Teaching intercultural English learning/teaching in world : Some classroom activities in South Korea. English Teaching: Practice and Critique 11(4): 190205.

Liddicoat, Anthony J., Leo Papademetre, Angela Scarino \& Michelle Kohler. 2003. Report on intercultural language learning. Canberra, ACT: Commonwealth of Australia.

McConachy, Troy \& Kaori Hata. 2013. Addressing textbook representations of pragmatics and culture. ELT Journal 67(3): 294-301. doi: 10.1093/elt/cct017

Mitchell, Rosamond \& Florence Myles. 2004. Second language learning theories (2nd edn.). London: Hodder Arnold.

Paige, R. Michael, Helen Jorstad, Laura Paulson, Francine Klein \& Jeanette Colby. 1999. Culture learning in language education: A review of the literature. In R. Michael Paige, Dale L. Lange, \& Yelena A. Yershova (eds.), Culture as the core: Integrating culture into the language curriculum (CARLA Working Paper Series 15), 47-114. Minneapolis, $\mathrm{MN}$ : The Center for Advanced Researchon Language Acquisition, University of Minnesota.

Paricio, Silvina. 2005. La dimensión cultural en los libros de texto de lenguas extranjeras: Pautas para su análisis. Glosas Didácticas 15. 133-144.

Puig, Gentil. 1996. Analyse du contenu ethnoculturel des manuels de langues étrangères. In Fermín Sierra Martínez, Mercè Pujol Berché \& Harm den Boer (eds.), Las lenguas en la Europa comunitaria II: La ensenanza de segundas lenguas y/o de lenguas extranjeras (Diálogos Hispánicos 18), 327-346. Amsterdam: Rodopi.

Risager, Karen. 1991. Cultural references in European textbooks: An evaluation of recent tendencies. In Dieter Buttjes \& Michael Byram (eds.), Mediating languages and cultures: Towards an intercultural theory of foreign language education (Multilingual Matters 60), 181-192. Clevedon: Multilingual Matters.

Risager, Karen. 1998. Language teaching and the process of European integration. In Michael Byram \& Michael Fleming (eds.), Language learning in intercultural perspective: 
Approaches through drama and ethnography (Cambridge Language Teaching Library), 242-254. Cambridge: Cambridge University Press.

Sercu, Lies. 2000. Textbooks. In Michael Byram (ed.), Routledge encyclopedia of language teaching and learning, 626-628. London \& New York, NY: Routledge.

Sercu, Lies. 2005. Teaching foreign languages in an intercultural world. In Lies Sercu et al. (eds.), Foreign language teachers and intercultural competence: An international investigation (Language for Intercultural Communication and Education 10), 1-18. Clevedon: Multilingual Matters.

Shin, Jeeyoung, Zohreh R. Eslami \& Wen-Chun Chen. 2011. Presentation of local and international culture in current international English-language teaching textbooks. Language, Culture and Curriculum 24(3). 253-268. doi: 10.1080/07908318.2011.614694

Tomlinson, Brian. 2012. Materials development for language learning and teaching. Language Teaching 45(2). 143-179. doi: 10.1017/S0261444811000528

Varón, Martha E. 2009. Componente cultural, libros de texto y enseñanza del inglés como lengua extranjera. Forma y Función 22(1). 95-124.

Ware, Paige D. \& Claire Kramsch. 2005. Toward an intercultural stance: Teaching German and English through telecollaboration. The Modern Language Journal 89(2).190-205. doi: $10.1111 / \mathrm{j} .1540-4781.2005 .00274 . \mathrm{x}$

Watson, Jeffrey R., Peter Siska \& Richard L. Wolfel. 2013. Assessing gains in language proficiency, cross-cultural competence, and regional awareness during study abroad: A preliminary study. Foreign Language Annals 46 (1). 62-79. doi: 10.1111/flan.12016

Weninger, Csilla \& Tamas Kiss. 2013. Culture in English as a Foreign Language (EFL) textbooks: A semiotic approach. TESOL Quarterly 47(4). 694-716. doi: 10.1002/tesq.87

Whorf, Benjamin L. 1956. Science and linguistics. In John B. Carroll (ed.), Language, thought, and reality: Selected writings of Benjamin Lee Whorf, 212-214. Cambridge, MA: Massachusetts Institute of Technology Press.

Zarei, Gholam R. \& Mahmood Khalessi. 2011. Cultural load in English language textbooks: An analysis of interchange series. Procedia: Social and Behavioral Sciences 15. 294301. doi: $10.1016 /$ j.sbspro.2011.03.089 